\title{
Pengalaman Orang Tua dalam Merawat Anak Berkebutuhan Khusus : Literature Review
}

\author{
Adisty Archi ${ }^{\mathrm{a}}$, Ajeng Sri ${ }^{\mathrm{a}}$, Al Waridlatul ${ }^{\mathrm{a}}$, Arum Fatmawati ${ }^{\mathrm{a}}$, Aulia Amalia ${ }^{\mathrm{a}}$, \\ Awaliyah Tri ${ }^{a}$, Ayu Ratna ${ }^{a}$, Clarissa Artiga ${ }^{a}$, Derisca Tiara ${ }^{a}$, \\ Badrul Munif ${ }^{\text {a }}$, Fransiska Erna Da
}

${ }^{a}$ Prodi S1 Keperawatan STIKES Banyuwangi, Indonesia

Email Korespondensi: MunifBadrul2@gmail.com

\begin{abstract}
Introduction: The presence of a child in the family is certainly very encouraging for parents. However, it is different from parents who have children with special needs. Children with special needs need different treatment from other children. This of course raises different experiences for each parent in their care. Objective: This study was to determine the psychosocial experience of parents in caring for children with special needs. Method: The method used in this paper is a literature review. With library sources, namely journal articles published in the 2020-2021 period which are full text. Search for journal articles using the Google Schoolar database with the keyword experience; parent; nurse; the child with special needs. Results: This study found 1,500 journal articles which the researchers then took according to the specified criteria, obtained as many as 10 articles. 10 articles reviewed by researchers found 3 journal articles on experiences of parents who can accept the condition of children with special needs and 7 articles found experiences of parents who have psychosocial problems in caring for children with special needs. Conclusion: This literature review found that the experience of parents in caring for $c$ hildren with special needs is divided into two where there are parents who can accept their child's condition sincerely and parents who experience psychosocial problems in the care of children with special needs such as stress, inferiority, shock, rejection, etc. How parents respond to their children with special needs is influenced by many factors such as age, environment, knowledge, etc.
\end{abstract}

Keywords: experience; parent; nurse; the child with special needed.

\begin{abstract}
Abstrak
Pendahuluan: Kehadiran seorang anak dalam keluarga tentu sangat menggembirakan bagi orang tua. Namun berbeda dengan orang tua yang memiliki anak berkebutuhan khusus. Anak yang berkebutuhan khusus perlu perawatan yang berbeda dengan anak-anak yang lainnya. Hal ini tentu memunculkan pengalaman yang berbeda pada setiap orang tua dalam perawatannya. Tujuan: Tujuan penelitian ini untuk mengetahui pengalaman psikososial orang tua dalam merawat anak berkebutuhan khusus. Metode: Metode yang digunakan dalam penulisan ini yaitu literature review. Dengan sumber pustaka yaitu artikel jurnal yang diterbitkan pada rentang waktu 2020-2021 yang full teks. Pencarian artikel jurnal menggunakan data base Google Schoolar dan Portal Garuda dengan kata kunci pengalaman; orang tua; merawat; anak berkebutuhan khusus. Hasil: Hasil penelitian ini menemukan 25 artikel jurnal yang selanjutnya peneliti ambil sesuai dengan kriteria yang ditentukan didapatkan sebanyak 10 artikel jurnal. 10 artikel yang dilakukan review peneliti menemukan 3 artikel jurnal pengalaman orang tua yang dapat menerima keadaan anak berkebutuhan khusus dan 7 artikel ditemukan pengalaman orang tua yang memiliki masalah psikososial dalam merawat anak berkebutuhan khusus. Kesimpulan: Literature review ini menemukan bahwa pengalaman orang tua dalam merawat anak berkebutuhan khusus terbagi menjadi dua dimana ada orang tua yang dapat menerima keadaan anak nya dengan ikhlas, dan orang tua yang mengalami masalah psikososial dalam perawatan anak berkebutuhan khusus seperti stress, minder, shock, penolakan, dll. Bagaimana respon orang tua terhadap anaknya yang memiliki kebutuhan khusus di pengaruhi oleh banyak faktor seperti faktor usia, lingkungan, pengetahuan, dll
\end{abstract}


Kata kunci: pengalaman; orang tua; merawat; anak berkebutuhan khusus

\section{PENDAHULUAN}

Jumlah anak berkebutuhan khusus
yang tercatat menempuh pendidikan di
sekolah luar biasa (SLB) mencapai 144.621
siswa pada tahun ajaran 2020/2021. Dari
jumlah tersebut, sebanyak 82.326 anak
berkebutuhan khusus berada di jenjang
pendidikan Sekolah Dasar. Sebanyak 36.884
anak berkebutuhan khusus tengah mengenyam
pendidikan di Sekolah Menengah Pertama (SMP). Sedangkan, ada 25.411 anak berkebutuhan khusus yang tengah menempuh Sekolah Menengah (Databoks, 2021)

Kelahiran seorang anak merupakan saat-saat yang dinantikan oleh pasangan suami-istri. Setiap orang tua memiliki harapan bahwa kelak anak yang lahir adalah anak yang sempurna, baik secara fisik maupun mental. Kegembiraan dan harapan akan masa depan yang cerah juga menyertai kelahiran seorang bayi. Namun, ketika bayi yang lahir dan mereka rawat ternyata didiagnosa menderita gangguan perkembangan, orang tua harus mau menerima kenyataan bahwa anak mereka memiliki kekurangan (Ignatia Dimarda Pamintaningtiyas1 2020).

Orang tua adalah orang yang paling bertanggung jawab terhadap pengasuhan, perawatan dan penanganan anak khususnya bagi orang tua yang memiliki anak berkebutuhan khusus sehingga orang tua memiliki peran yang sentral dalam membantu perkembangan anak. Kewajiban itu menjadi tanggung jawab bersama antara ayah dan ibu sehingga bisa berbagi peran dalam upaya merawat anak dengan baik namun ibu memiliki tugas pokok yang lebih banyak dalam pengasuhan dan perawatan anak (Sujito 2017).

Anak merupakan anugerah dan harapan bagi setiap keluarga. Semua pasangan suami istri menginginkan kehadiran seorang anak yang tentu jasmani dan rohaninya sehat hingga memberikan perubahan baru dan menambah kebahagiaan dalam keluarga (Dwidiyanti et al. 2021). Namun seperti yang sudah diketahui beberapa anak dilahirkan dengan kondisi yang kurang sempurna. Cukup banyak anak yang dilahirkan dengan membutuhkan perhatian spesial atau keterbatasan fisik maupun mental. Anak dengan kebutuhan khusus memiliki makna anak dengan gangguan perkembangan mental atau intelektual, sosial, dan emosional (Permatasari 2021).

\section{METODE}

Metode yang digunakan dalam penelitian ini adalah literature review. Artikel yang di review menggunakan metode penelitian kualitatif dengan pendekatan studi kasus deskriptif. Dengan sumber pustaka yaitu artikel jurnal yang diterbitkan pada rentang waktu 2020-2021 tahun yang full teks. Pencarian artikel jurnal menggunakan database Google Schoolar dan Portal Garuda dengan kata kunci pengalaman; orang tua; merawat; anak berkebutuhan khusus.

\section{HASIL}

Hasil penelitian ini menemukan 25 artikel jurnal yang selanjutnya peneliti ambil sesuai dengan kriteria yang ditentukan didapatkan sebanyak 10 artikel. 10 artikel yang dilakukan review peneliti menemukan 3 artikel jurnal pengalaman orang tua yang dapat menerima keadaan anak berkebutuhan khusus dan 7 artikel ditemukan pengalaman orang tua yang memiliki masalah psikososial dalam merawat anak berkebutuhan khusus. Penelitian ini mengenai pengalaman orang tua dalam merawat anak berkebutuhan khusus memunculkan 2 hasil pembahasan meliputi: Orang tua yang dapat menerima keadaan anak berkebutuhan khusus dan Orang tua yang memiliki masalah psikososial dalam merawat anak berkebutuhan khusus. 


\section{PEMBAHASAN}

Kehadiran seorang anak dengan kebutuhan khusus mungkin bukanlah hal yang diharapkan setiap keluarga, orang tua akan dihadapkan dengan rasa bersalah dan kekecewaan karena anak yang dinanti mengalami kelainan dan berbeda dengan anak-anak normal lainnya, namun pada hakekatnya mereka tetaplah seorang anak dan orang tua tetaplah orang tua dan pada dasarnya anak berkebutuhan khusus sangatlah memerlukan pengasuhan yang lebih besar dibandingan dengan merawat anak-anak normal.

Berdasarkan hasil analisis data penelitian yang telah dilakukan, peneliti telah mengidentifikasi beberapa pembahasan yang mengacu pada tujuan penelitian yaitu bagaimana status psikososial orang tua dalam merawat anak berkebutuhan khusus. Dalam merawat anak berkebutuhan khusus, tentu saja orang tua mengalami reaksi dan respon yang berbeda dalam perawatannya. Beberapa dari orang tua dapat menerima dan ada beberapa dari orang tua yang merasakan stress, cemas, khawatir, shock, penolakan sejak anaknya lahir hingga anaknya beranjak dewasa.

\section{Orang tua yang dapat menerima keadaan anak berkebutuhan khusus.}

Terdapat 3 dari 10 artikel jurnal yang menyebutkan bahwa bebeberapa orang tua dapat menerima dengan ikhlas dan sabar atas keadaan anaknya. Meskipun dalam perawatan anak berkebutuhan khusus tentunya berbeda dengan perawatan anak yang normal pada umumnya, tetapi para orang tua cukup sabar dalam melalui maupun mepersiapkan kehidupan yang baik di hari ini, maupun di masa depan anaknya.

- Artikel Jurnal 1 "Pengalaman Orang Tua Anak Berkebutuhan Khusus Mengenai Pembelajaran Daring Selama Covid-19" Dukungan emosional ditunjukkan oleh salah satu subjek yang menyatakan bahwa dia cukup bersabar dalam meng-

hadapi perilaku anak selama belajar. Dia merasa bahwa ia menjadi lebih sabar dalam menghadapi anaknya yang kadang susah untuk diajak belajar dan diminta menyanyi. Melalui belajar daring, orang tua melihat juga bahwa ada perkembangan positif baik fisik maupun non-fisik anak seperti fisiknya yang menjadi jarang sakit, kemandirian, kreativitas serta tanggung jawab. Dukungan emosional ditunjukkan oleh salah satu subjek yang menyatakan bahwa dia cukup bersabar dalam menghadapi perilaku anak selama belajar (Permata Sari and Paska 2021)

- Artikel Jurnal 2 "Pengalaman Orang Tua dalam Mengasuh Anak Down Syndrome pada Masa Pandemi Covid-19" Apabila didalam keluarga terdapat penerimaan, terutama pada ibu maka akan mempermudah pengasuhan dan memengaruhi perkembangan anak down syndrome menjadi lebih baik. Di sisi lain orang tua merasa senang dengan kehadiran anak tersebut dan merasa bersyukur seperti yang diungkapkan bahwa tidak ada masalah dengan kebutuhan anak karena rejeki selalu saja ada, anaknya justru memberikan keberkahan bagi keluarganya. Orang tua merasa senang dengan kehadiran anak tersebut dan merasa bersyukur seperti yang diungkapkan oleh participant bahwa tidak ada masalah dengan kebutuhan anak karena rejeki selalu saja ada, anaknya justru memberikan keberkahan bagi keluarganya (Permatasari 2021).

- Artikel Jurnal 3 "Peran Orang Tua Single Parent Terhadap Anak Down Syndrom di Bypass Kecamatan Lubuk Begalung" Penanganan anak penderita down syndrome adalah keikhlasan dari para orang tua baik kedua orang tua yang masih utuh maupun orang tunggal atau single parent dengan menerima keadaan sang buah hati Dengan adanya perasaan ikhlas dari orangtua, si anak dapat tumbuh dan berkembang dengan baik, serta merasa 


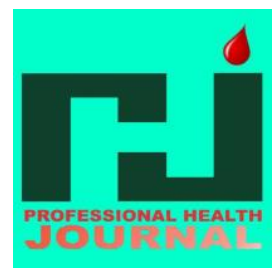

bahagia karena kehadirannya diterima. Hasil penelitian yang telah dilakukan dapat dilihat dari mengambil keputusan bahwa single parent menerima keadaan dengan

ikhlas ketika mengetahui anak mengalami down syndrome. Menurut single parent memiliki anak down syndrome adalah suatu anugerah yang diberikan oleh Tuhan, dalam menyesuaikan diri dengan memiliki anak down syndrome, single parent selalu berusaha memahami keadaan anak yang sangat memiliki keterbatasan tersebut (Melati and Mulyani 2021).

Seperti yang telah kami teliti dari beberapa artikel jurnal orang tua dengan anak berkebutuhan khusus tentu saja pada awalnya akan merasakan shock dan cemas. Namun beberapa dari orang tua bahkan merasa bersyukur dan bisa langsung menerima keadaan anaknya dan menganggap bahwa anak merupakan rejeki yang tuhan berikan apapun keadaannya. Penerimaan orang tua dapat dipengaruhi oleh faktor ekonomi, faktor sosial, dan faktor pengetahuan, dll dengan seiring berjalannya waktu dan bertambahnya pengetahuan maka semakin orang tua bisa menerima keadaan anaknya.

\section{Orang tua yang memiliki masalah psikososial dalam merawat anak berkebutuhan khusus.}

Terdapat 7 dari 10 artikel jurnal yang menyebutkan bahwa beberapa orang tua mengalami stress, kecemasan, kekhawatiran, minder dan juga penolakan ketika mengetahui keadaan anaknya.

- Artikel Jurnal 1 "Konsep Diri dan Resiliensi Orang Tua yang Memiliki Anak Tunagrahita" menjelaskan mayoritas orang tua yang mempunyai anak berkebutuhan khusus tunagrahita memiliki konsep diri yang negative (36,8\%). Konsep diri merupakan pandangan terhadap diri kita sendiri dalam merefelksikan pengalaman interaksi sosial. Konsep diri dipengaruhi dengan kehadiran orang lain yang kita
PROFESIONAL HEALTH JOURNAL

Volume 3, No. 1, Desember 2021 (Hal. 19-25)

https://www.ojsstikesbanyuwangi.com/index.php/PHJ

anggap penting dalam hidup. Orang tua dalam memiliki anak berkebutuhan khusus biasanya merasa resah, malu, marah, sedih, depresi dan berusaha menolak kenyataan (Putri, Suryani, and Daeli 2021).

- Artikel Jurnal 2 "Dinamika Gratitude pada Ibu yang Memiliki Anak Down Syndrome" menjelaskan bahwa ibu yang memiliki anak down syndrome merasakan psikis dan mentalnya tergangu yang dirasakan oleh ibu merupakan suatu peristiwa yang harus dihadapi dan sebagai tantangan bagi ibu. Walaupun seringkali ibu merasa terbebani dengan kesulitan yang ada. Reaksi pada orangtua yang memiliki anak berkebutuhan khusus pada umumnya ialah merasa shock dan terganggu, penolakan, kesedihan, kecemasan dan ketakutan, marah dan kemudian akan meyesuaikan diri (Teguh and Prasetyo 2021).

- Artikel Jurnal 3 "Pengalaman Orang Tua Dalam Merawat Anak Dengan Attention Deficit Hyperactivity Disorder (ADHD)" Penelitian ini mendapatkan fenomenologi yang berdasarkan pada pengalaman hidup ibu dalam merawat anak Perilaku hiperaktif yang ditunjukkan anak sering menjadi penghambat ketika anak bersosialisasi. Ibu mengeluh bahwa anaknya tidak merespon saat dipanggil, tidak memperhatikan saat diajak mengobrol, tidak memperhatikan saat dinasehati, sibuk bermain sendiri, tidak mau bermain dengan temannya tidak dapat bertahan lama ketika bermain satu permainan (Prasetyawan, Rosuli, and Munif 2021). Pada awal kehidupan anak, keluarga partisipan cenderung mengalami penolakan terhadap kondisi anak, marah dan kecewa dirasakan oleh keluarga anak. Seiring berjalannya waktu, keluarga mulai menerima kondisi anak dan pasrah kepada tuhan terhadap keadaan dan kondisi anak (Puji Utami et al. 2021).

- Artikel Jurnal 4 "Pengalaman Orang Tua Dalam Merawat Anak Retardasi Mental" 


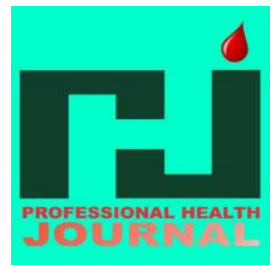

Hasil penelitian ini menunjukkan pengalaman orang tua dalam merawat anak retardasi mental adalah partisipan 1 merasa tidak percaya, partisipan 2 merasa shock, partisipan 3 merasa sedih, partisipan 4 merasa kecewa dan bersalah dan partisipan 5 merasa marah dan menolak, dan muncul bahwa beberapa

respons psikologis yang dialami oleh orangtua diantaranya merasa kaget, merasa syok dan merasa pasrah. Banyak orang tua yang tidak mengizinkan anaknya bermain bersama teman-teman dilingkungannya karena rasa minder pada diri orangtua (Padila et al. 2021).

- Artikel Jurnal 5 "Studi Fenomenologi Pengalaman Orang Tua dalam Memandirikan Anak Usia (0-18 Tahun) dengan Retardasi Mental Sedang di SLB Negeri Batulicin Kabupaten Bumbu 2019" Dalam penelitian ini orang tua masuk dalam proses denial yaitu, merasa kaget, merasa syok dan merasa pasrah, karena ini adalah proses penerimaan dimana setiap orang yang mengalami hal yang diluar dengan apa yang diharapkan apalagi itu menyangkut dengan suatu hal yang penting didalam hidupnya pasti akan berat jika harus menerima kenyataan seperti ini yaitu memiliki anak dengan retardasi mental. Perasaan orang tua saat mengetahui anak mereka mengalami retardasi mental beberapa dari orang tua mengungkapkan bahwa mereka sedih dengan kenyataan yang terjadi. Reaksi pertama orang tua ketika anaknya dikatakan bermasalah adalah tidak percaya, shock, sedih, kecewa, mersa bersalah, marah dan menolak. Tidak mudah bagi orang tua yang anaknya menyandang kecacatan untuk mengalami penerimaan. Ada masa orang tua merenung dan tidak mengetahui apa yang harus diperbuat (Rahmadayanti, Atmaja, and Udiyani 2020).

- Artikel Jurnal 6 "Peran Orang Tua Anak Berkebutuhan (Autis) Sekolah Dasar Selama Masa Covid-19" Penelitian tentang Dukungan Sosial yang diberikan pada Ibu anak autis dengan Stres yang dialami oleh
PROFESIONAL HEALTH JOURNAL

Volume 3, No. 1, Desember 2021 (Hal. 19-25)

https://www.ojsstikesbanyuwangi.com/index.php/PHJ
Ibu. Hasilnya tidak ada hubungan yang signifikan antara stres ibu dengan dukungan sosial yang diberikan pada anak autis (Primasari and Supena 2020).

- Artikel Jurnal 7 "Hubungan antara Work Family Conflict dengan Psychological Well-Being pada Ibu yang bekerja sebagai Perawat di Rumah Sakit Sumber Kasih"

Stress pengasuhan juga dipahami sebagai kesulitan yang muncul sebagai bentuk tuntutan peran menjadi orang tua, yang mempengaruhi perilaku dan well-being orang tua (Pamintaningtiyas and Soetjiningsih 2020).

Dari penelitian yang telah kami lakukan, tidak jarang orang tua yang tidak bisa menerima keadaan anaknya saat mengetahui anaknya mengalami berkebutuhan khusus. Hal ini berpengaruh pada status psikososial orang tua dalam melakukan pengasuhan pada anak berkebutuhan khusus mulai sejak lahir, hingga anak memasuki waktu sekolah dan beranjak dewasa. Tak jarang pengaruh dari lingkungan sosial juga menentukan seberapa tingkat stress orang tua karena beberapa dari lingkungan sosial orang tua terkadang kurang memberi dukungan sehingga timbulnya perasaan cemas, stress, minder secara berkepanjangan.

\section{KESIMPULAN DAN SARAN}

Terdapat 3 dari 10 artikel jurnal yang menyebutkan bahwa beberapa orang tua dapat menerima keadaan anak berkebutuhan khusus tentunya berbeda dengan perawatan anak yang normal pada umumnya. Orang tua ini cukup sabar dan ikhlas mempersiapkan kehidupan anaknya, orang tua ini juga merasa sangat senang dengan adanya kehadiran anak tersebut dan merasa bersyukur Tuhan memberinya anugerah di keluarganya. Dari sini kita dapat mengambil keputusan bahwa orang tua menerima keadaan anaknya dengan ikhlas mengetahui anak mengalami berkebutuhan khusus. 
Selanjutnya terdapat 7 dari 10 artikel jurnal bahwa beberapa memiliki anak berkebutuhan khusus biasanya merasa minder, malu, marah, sedih dan juga depresi melihat kondisi anaknya tersebut, pada awal kehidupan anak, keluarga ini cenderung mengalami penolakan terhadap kondisi anak, marah dan kecewa dirasakan oleh keluarganya, penelitian ini berisi tentang

bagaimana pengalaman orang tua dalam merawat anak berkebutuhan khusus. Berdasarkan hasil tinjauan literature peneliti mengemukakan saran sebagai berikut :

1. Bagi Orang tua/keluarga

Disarankan agar dalam menjaga anak berkebutuhan khusus lebih memberikan perhatian dan kasih sayang yang lebih, dan memberikan dukungan sosial kepada anak berkebutuhan khusus. Dan juga melakukan komunikasi dengan baik, agar hidup anak berkebutuhan khusus lebih bermakna.

2. Bagi Universitas

Hasil literatur review ini dapat digunakan sebagai bahan bacaan dan referensi di perpustakaan sebagai sarana untuk meningkatkan ilmu pengetahuan dan wawasan dibidang keperawatan.

3. Bagi Peneliti Selanjutnya

Hasil penelitian ini dapat digunakan untuk menunjang literature review untuk penelitian lebih lanjut, namun disarankan untuk memperdalam permasalahan misalnya dengan menanyakan lebih jauh mengenai respon orang tua terhadap anak berkebutuhan khusus serta masalah psikologis yang orang tua alami saat merawat anak berkebutuhan khusus

\section{DAFTAR PUSTAKA}

Dwidiyanti, Meidiana, Badrul Munif, Agus Santoso, Ashri Maulida Rahmawati, and Rikhan Luhur Prasetya. 2021. "DAHAGA : An Islamic Spiritual Mindfulness-Based Application to Reduce Depression among Nursing Students during the COVID-19 Pandemic." 7(3):219-26.

Melati, R., and R. R. Mulyani. 2021. "Peran
Orang Tua Single Parent Terhadap Anak Down Syndrome Di Bypass Kecamatan Lubuk Begalung:(Studi Kasus Pada Ayah Yang Memiliki Anak Down ...." Edu Society: Jurnal ... 5(1):1007-16.

Padila, Harsismanto J, Bagus Andrianto, Andry Sartika, and Septeah Ningrum. 2021. "Pengalaman Orang Tua Dalam Merawat Anak Retardasi Mental." Jurnal Kesmas Asclepius 3:9-16.

Pamintaningtiyas, Ignatia Dimarda, and Christiana Hari Soetjiningsih. 2020. "Hubungan Antara Work Family Conflict Dengan Psychological WellBeing Pada Ibu Yang Bekerja Sebagai Perawat Di Rumah Sakit Sumber Kasih Cirebon." Psikologi Konseling 16(1):581-89.

Permata Sari, Diana, and Stephani Paska. 2021. "Pengalaman Orang Tua Anak Berkebutuhan Khusus Mengenai Pembelajaran Daring Selama Pandemi COVID-19." JPK (Jurnal Pendidikan Khusus) 17(1):11-19.

Permatasari, Firza Zhela. 2021. "Pengalaman Orang Tua Dalam Mengasuh Anak Down Syndrome Pada Masa Pandemi Covid-19."

Prasetyawan, Riyan Dwi, Ahmad Rosuli, and Badrul Munif. 2021. "Standar Discharge Planning Terhadap Keterampilan Ibu Primipara Dalam Memandikan Bayi Baru Lahir." Laboratorium Penelitian Dan Pengembangan FARMAKA TROPIS Fakultas Farmasi Universitas Mualawarman, Samarinda, Kalimantan Timur 3(Juni):319-25.

Primasari, Ika Firma Ningsih Dian, and Asep Supena. 2020. "Peran Orang Tua Anak Berkebutuhan Khusus (Autis) Sekolah Dasar Selama Masa Covid19." Jurnal Sekolah PGSD FIP UNMED 5(1):133-42.

Puji Utami, Ratih Dwi Lestari, Wahyuningsih Safitri, Christiani Bumi Pangesti, and Nur Rakhmawati. 2021. 
"Pengalaman Orang Tua Dalam Merawat Anak Dengan Attention Deficit Hyperactivity Disorder (Adhd)." Jurnal Kesehatan Kusuma Husada 12(2):222-30.

Putri, Eugennia Sakanti, Ketut Suryani, and Novita Elisabeth Daeli. 2021. "Konsep Diri Dan Resiliensi Orangtua Yang Memiliki Anak Tunagrahita Fakultas Ilmu Kesehatan Universitas Katolik Musi Charitas Palembang." Jumantik 6(1):6569.

Rahmadayanti, Nadia Solehah, Bayu Purnama Atmaja, and Ritna Udiyani. 2020. "Phenomenology Study Studi Fenomenologi Pengalaman Orang Tua Dalam Memandirikan Anak Usia (0-18 Tahun) Dengan Retardasi Mental Sedang Di Slb Negeri Batulicin Kabupaten Tanah Bumbu 2019." Jurnal Keperawatan Suaka Insan (Jksi) 5(1):1-7.

Sujito, Edi. 2017. "Dinamika Karakter Orang Tua Yang Memiliki Anak Berkebutuhan Khusus.”1-91.

Teguh, Pipit Meidy, and Eli Prasetyo. 2021. "Dinamika Gratitude Pada Ibu Yang Memiliki Anak Down Syndrome.” Jurnal Psikologi Indonesia 9(1):1-9. 